\title{
ELECTRICAL CONDUCTIVITY AND ACIDITY OF HONEY
}

\author{
Milica Živkov Balošił, Nenad Popov ${ }^{1}$, Suzana Vidaković ${ }^{1}$, \\ Dragana Ljubojević Pelić ${ }^{1}$, Miloš Pelić ${ }^{1}$, Željko Mihaljev $^{1}$, Sandra Jakšić ${ }^{1}$ \\ ${ }^{1}$ Scientific Veterinary Institute "Novi Sad", Novi Sad, Serbia
}

\begin{abstract}
In this paper, the electrical conductivity and concentration of free acids (acidity) of various types of honey collected from the area of Vojvodina was investigated. Physicochemical analyzes of parameters such as electrical conductivity and acidity of honey have an important role in defining the overall properties of honey and assessing the quality of honey. A total of 55 samples of honey were examined. Out of the total number of samples, 5 samples did not meet the requirements of the Republic of Serbia Regulations on quality of honey due to inadequate electrical conductivity. Free acid values measured in tested samples ranged from 1.5 to $30 \mathrm{mEq} / \mathrm{kg}$, and the values of electrical conductivity were in the range between 0.08 and $1.99 \mathrm{mS} / \mathrm{cm}$. Our assumption that there is a correlation between the tested parameters has been confirmed only in meadow and polyfloral honey. Further research on the physicochemical properties of Serbian honey is recommended and important in order to establish certification marks and criteria for assessing the quality of Serbian honey.
\end{abstract}

Keywords: honey, electrical conductivity, acidity

\footnotetext{
${ }^{1}$ Corresponding author: milica@niv.ns.ac.rs
} 


\title{
ELEKTRIČNA PROVODLJIVOST I SLOBODNE KISELINE U MEDU
}

\author{
Milica Živkov Baloš ${ }^{1 *}$, Nenad Popov ${ }^{1}$, Suzana Vidaković ${ }^{1}$, \\ Dragana Ljubojević Pelić ${ }^{1}$, Miloš Pelić ${ }^{1}, Z_{\text {Zljiko Mihaljev }}{ }^{1}$, Sandra Jakšić ${ }^{1}$ \\ ${ }^{1}$ Naučni institut za veterinarstvo "Novi Sad”, Novi Sad, Srbija
}

\section{Kratak sadržaj}

U ovom radu ispitivana je električna provodljivost i koncentracija slobodnih kiselina (kiselost) različitih vrsta meda koji je prikupljena sa područja Vojvodine. Fizičko-hemijske analize parametara kao što su električna provodljivost i kiselost meda imaju značajnu ulogu u definisanju ukupnih svojstava meda i proceni kvaliteta meda. Ispitano je ukupno 55 uzoraka meda. Od ukupnog broja uzoraka 5 uzoraka nije ispunilo zahteve Pravilnika Republike Srbije o kvalitetu meda, zbog neodgovarajuće električne provodljivosti. Izmerene vrednosti za slobodne kiseline $\mathrm{u}$ ispitivanim uzorcima kretale su se u opsegu od 1,5 mEq/kg do $30 \mathrm{mEq} / \mathrm{kg}$, a vrednosti električne provodljivosti u opsegu od 0,08 do $1,99 \mathrm{mS} / \mathrm{cm}$. Naša pretpostavka da postoji korelacija između ispitivanih parametara potvrđena je se samo kod livadskog i polifloranog meda. Dalje istraživanje fizičkohemijskih osobina srpskog meda veoma je preporučljivo i važno, kako bi se uspostavile sertifikacione oznake i poboljšali kapaciteti lokalnog pčelarstva.

Ključne reči: med, električna provodljivost, slobodne kiseline

\section{INTRODUCTION}

According to the Codex Alimentarius honey is defined as "natural sweet substance produced by honey bees from the nectar of plants or from secretions of living parts of plants or excretions of plant sucking insects on the living parts of plants, which the bees collect, transform by combining with specific substances of their own, deposit, dehydrate, store, and leave in the honey comb to ripen and mature". Bees produce honey to serve as a source of food in times of scarcity or during bad weather conditions (Codex, 2001). Natural honey is one of the highly sought natural products because of its unique, highly nutritive and medicinal properties. These properties are attributed to the influence of different groups of substances that honey contains. Honey is unique sweet 
natural product that can be used in human nutrition without any further processing. The quality of honey and bee products depends on its origin. Active components in plants depend on various factors and climatic conditions in different geographical locations (Vidaković et al., 2017).

The conductivity is very often used in routine honey quality control. This property of honey is considered very good criterion for assessment of botanical origin and purity of honey. Among other things, honey contains components such as organic acids and minerals, which in an aqueous solution have the ability to dissociate into the ions or to conduct an electric power. The bright colour of honey usually points to a lower conductivity than dark colour of honey (Kropf et al., 2008). The electrical conductivity of honey is defined as that of a $20 \%$ weight in volume solution in water at $20^{\circ} \mathrm{C}$, where the $20 \%$ refers to honey dry matter (International Honey Commission, 2009). The measurement of electrical conductivity points indirectly to the ashes content of honey (Accorti et al., 1987). The ashes of honey give an indication of environmental pollution and hence also an indication of geographical origin. The electrical conductivity of the honey is related to the concentration of mineral salts, organic acid and proteins and proved to be useful for discriminating honeys of different floral origins (Acquarone et al., 2007). Other factors, such as floral source, amount of organic acids and proteins, and storage time can also influence the electric conductivity of honey (Karabagias et al., 2014). High electric conductivity values do not necessarily correspond to higher amounts of ash in the honey (Escuredo et al., 2014). Exact classification of honey must be carried out not only by measuring the conductivity but also in relation to optical rotation and microscopic analysis (Přidal and Vorlová, 2002).

The acidity of honey is caused by organic acids (tartaric, citric, oxalic, acetic, etc.), nectar or bees secretions (Yadata, 2014). The acidity of honey may be determined by titration with sodium hydroxide (free acidity) or directly measuring the $\mathrm{pH}$ value ( $\mathrm{pH}$ value). The natural acidity of honey can be increased by the storage and ripening of honey, as well as during the fermentation of honey. Honey that is adulterated with sugar syrup has very low acidity $(<1)$, while honey that is adulterated with invert sugar has a pronounced high acidity (Yadata, 2014). The acidity value related to the balance of organic acids naturally present in honey varies according to the floral source and the bee species (Sousa et al., 2016).

In accordance with the regulation concerning the quality of honey in the Republic of Serbia (Official Gazette, 101/2015), minimum electrical conductivity in honeydew put in the market is fixed to $0.8 \mathrm{mS} / \mathrm{cm}$. For other types of honey, the maximum permitted value of electrical conductivity is $0.8 \mathrm{mS} / \mathrm{cm}$. 
Maximum value of free acidity in all types of honey (except in baker's honey) is $50 \mathrm{mEq} / \mathrm{kg}$ as set by regulation (Official Gazette, 101/2015)

The purpose of this study was to determine electric conductivity and free acidity of honey collected in an official monitoring in the Republic of Serbia during October 2017, in order to obtain information about the honey quality and safety. In our research, which is a part of a study of the physicochemical and sensory characteristics of Serbian unifloral and mixed honey, the behaviour of honey was examined with respect to the electric conductivity and free acidity.

\section{MATERIAL AND METHODS}

\section{Honey samples}

In total, 55 honey samples were collected from different retail chains in Vojvodina region (northern Serbia). All samples were collected as a part of official monitoring of honey and bee products quality during October 2017.

All collected samples were in their original packaging and transferred to the laboratory of Scientific Veterinary Institute "Novi Sad" for examination.

A total of 55 investigated samples included 16 samples of acacia honey, 18 samples of meadow honey, 9 samples of floral honey, 6 samples of linden honey, and 6 samples of honeydew honey.

\section{Physicochemical analysis}

\section{Water content}

Water content was determined by refractometry, measuring the refractive index (RI) according to Harmonised methods of the International Honey Commission Methods (2009), using a standard model Abbetype refractometer a $20^{\circ} \mathrm{C}$. Water content (\%) was then obtained from the Chataway table.

\section{Electrical conductivity}

Electrical conductivity was measured at $20{ }^{\circ} \mathrm{C}$ in solutions of honey samples (20.0 g dry matter of honey in volume solution in $100 \mathrm{ml}$ distilled water) using a conductometer Crison (Type Basic 30). Method of measuring is prescribed by International Honey Commission Methods (2009).

\section{Free acidity}

The acidity of honey was determined by volumetric method (International Honey Commission Method, 2009). Ten grams of honey were dissolved in 75 
$\mathrm{ml}$ of distilled water and solution was titrated with $0.1 \mathrm{M} \mathrm{NaOH}$ to $\mathrm{pH} 8.30$. Acidity is expressed in milliequivalents $/ \mathrm{kg}$ honey $(\mathrm{mEq} / \mathrm{kg})$.

\section{Statistical analysis}

Statistical linear regression analysis was performed by the PAST software package, version 2.12, Oslo, Norway. Data were grouped according to the type of honey and presented as mean \pm standard error, minimum and maximum values.

\section{RESULTS AND DISCUSSION}

Average values of electrical conductivity and acidity of honey obtained in this study are summarized in Table 1 .

Table 1 Results of determining electrical conductivity and acidity in diverse honey samples

\begin{tabular}{|c|c|c|c|c|c|}
\hline \multirow{2}{*}{$\begin{array}{l}\text { TYPE OF } \\
\text { HONEY }\end{array}$} & \multirow{2}{*}{$\begin{array}{c}\text { No. of } \\
\text { sam- } \\
\text { ples }\end{array}$} & \multicolumn{2}{|c|}{$\begin{array}{l}\text { Electrical conduc- } \\
\text { tivity }(\mathrm{mS} / \mathrm{cm})\end{array}$} & \multicolumn{2}{|c|}{ Acidity (mEq/kg) } \\
\hline & & Range & $\begin{array}{c}\text { Average } \\
\text { value } \\
\pm S D\end{array}$ & Range & $\begin{array}{c}\text { Average value } \\
\pm \mathrm{SD}\end{array}$ \\
\hline $\begin{array}{c}\text { Meadow } \\
\text { honey }\end{array}$ & 18 & $0.08-1.19$ & $0.49 \pm 0.30$ & $1.5-30.0$ & $13.08 \pm 8.41$ \\
\hline Acacia honey & 16 & $0.08-0.30$ & $0.18 \pm 0.07$ & $2.5-9.0$ & $5.44 \pm 1.56$ \\
\hline Linden honey & 6 & $0.65-1.03$ & $0.82 \pm 0.13$ & $4.0-24.0$ & $12.17 \pm 6.73$ \\
\hline $\begin{array}{c}\text { Polyfloral } \\
\text { honey }\end{array}$ & 9 & $0.09-0.74$ & $0.46 \pm 0.18$ & $5.0-26.0$ & $13.61 \pm 6.12$ \\
\hline Forest honey & 6 & $0.09-1.99$ & $1.12 \pm 0.68$ & $5.0-29.0$ & $19.33 \pm 8.70$ \\
\hline
\end{tabular}

The obtained values were compared with the values that are prescribed by Regulation on the quality of honey in the Republic of Serbia (Official Gazette, 101/2015). The results were compared with the results from other authors from Serbia and other countries.

The water content values in all investigated honey samples were below $20 \%$, which is the maximum permitted level set by local regulations for honeys (Official Gazette, 101/2015).

Free acidity in all tested samples was below $50 \mathrm{mEq} / \mathrm{kg}$. These data indi- 
cated the absence of undesirable fermentation. A wide range of acidity values was found after the analysis of all honeys (Table 1). The acidity values in the investigated samples ranged from $1.5 \mathrm{mEq} / \mathrm{kg}$ to $30 \mathrm{mEq} / \mathrm{kg}$. Our results also demonstrated low acidity of acacia honey and high acidity of forest honey, as compared with other examined honey types. The composition of organic acids in honey has not yet been adequately investigated; however, some evidence suggest that acacia, chestnut and meadow honeys are characterized by particularly low contents of organic acids, while darker honeys in general appear to be higher in acidity (Prica et al., 2014). Very similar results were obtained in our earlier research (Prica et al., 2014). Similar results of honey free acidity were reported by other authors from other Mediterranean countries (Boussaid et al., 2018; Chakir et al., 2016; Yadata, 2014; Kirs et al., 2011; Sousa et al., 2016).

Electrical conductivity, closely related to the concentration of mineral and organic acids, showed a high variability within and between groups of honey. Values of electrical conductivity in the investigated honey samples were between 0.08 and $1.99 \mathrm{~ms} / \mathrm{cm}$. Out of a total of 55 tested honey samples, 5 samples did not comply with the local regulations for honeys (Official Gazette, 101/2015). Within the group of meadow honey, electrical conductivity was above $0.8 \mathrm{mS} /$ $\mathrm{cm}$ in one of 18 tested samples. In the group of linden honey, electrical conductivity was above $0.8 \mathrm{mS} / \mathrm{cm}$ in two from 6 tested samples. Within the group of forest honey, electrical conductivity value below $0.8 \mathrm{mS} / \mathrm{cm}$ was established in two from the total of 6 tested samples.

The data indicated lowest conductivity in acacia honey samples, while the highest conductivity is found in samples of forest and linden honey. Similar values for electrical conductivity of honey are reported by other authors from our and other countries (Vranić et al., 2017; Acquarone et al., 2007; Accorti et al., 1987; Boussaid et al., 2018; Chakir et al., 2016; Yadata, 2014; Kirs et al., 2011; Sousa et al., 2016; Escuredo et al., 2014; Karabagias et al., 2014).

Because both investigated properties are a function of the concentration of the ions present in the honey solution, their correlation was investigated (Figures 1 - 5). 


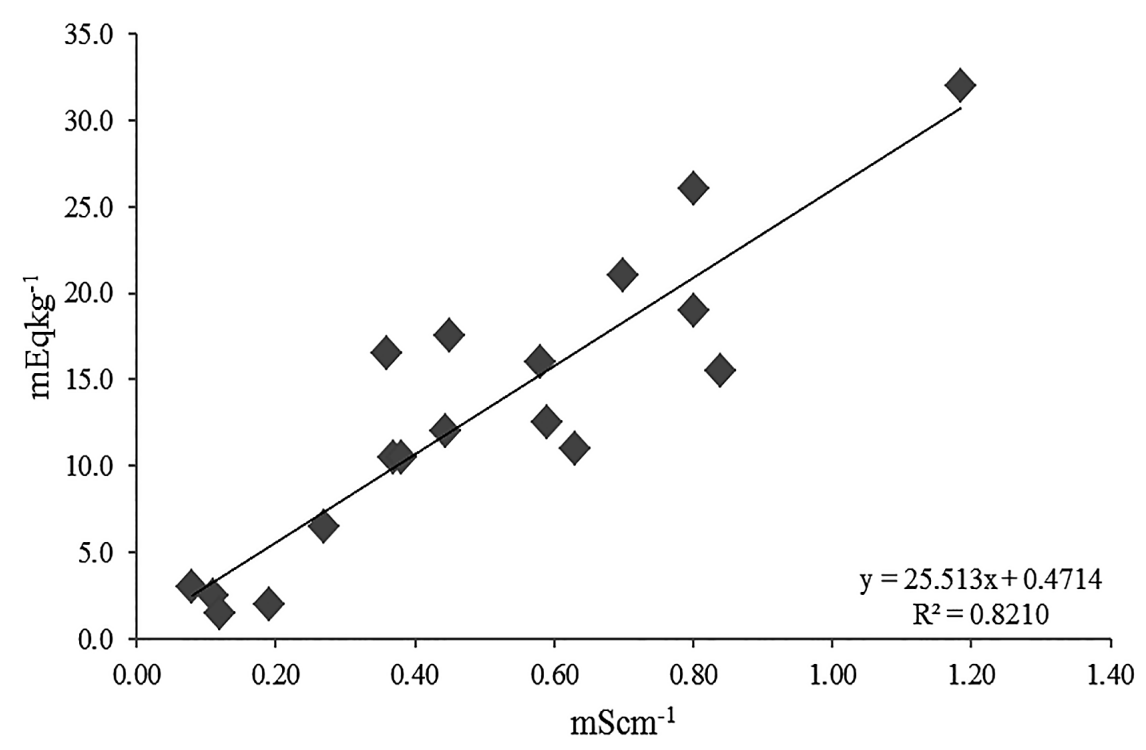

Figure 1. Correlation between acidity and electrical conductivity calculated for meadow honey samples.

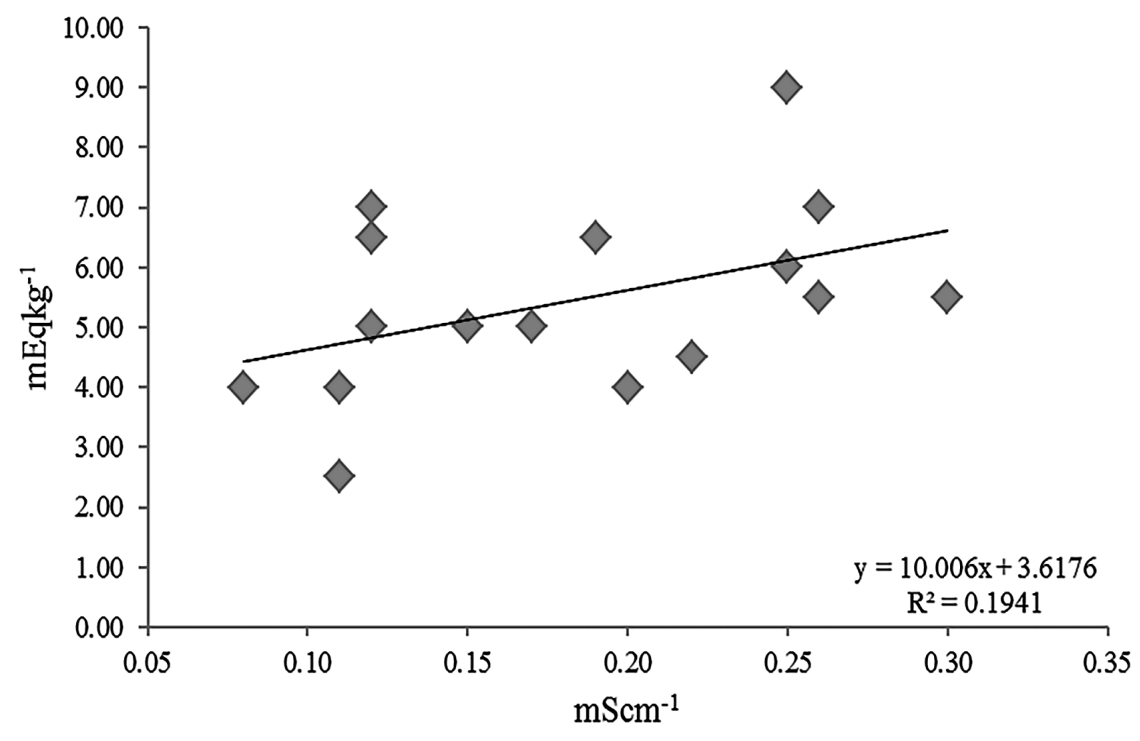

Figure 2. Correlation between acidity and electrical conductivity calculated for acacia honey samples. 


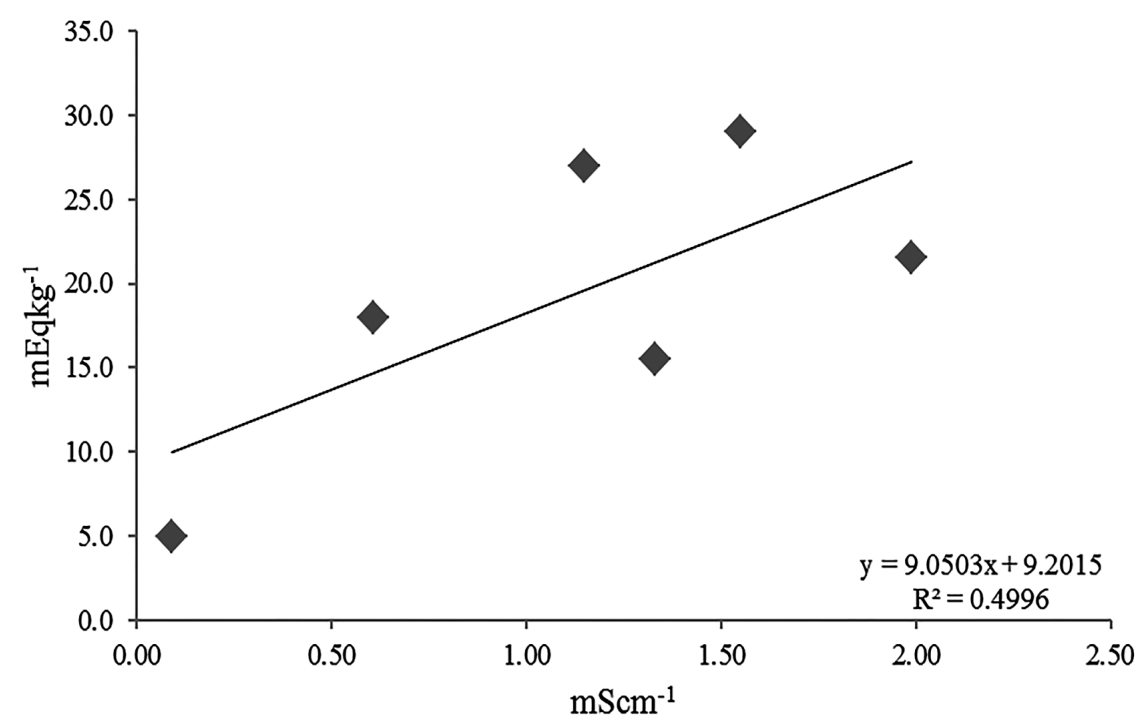

Figure 3. Correlation between acidity and electrical conductivity calculated for linden honey samples.

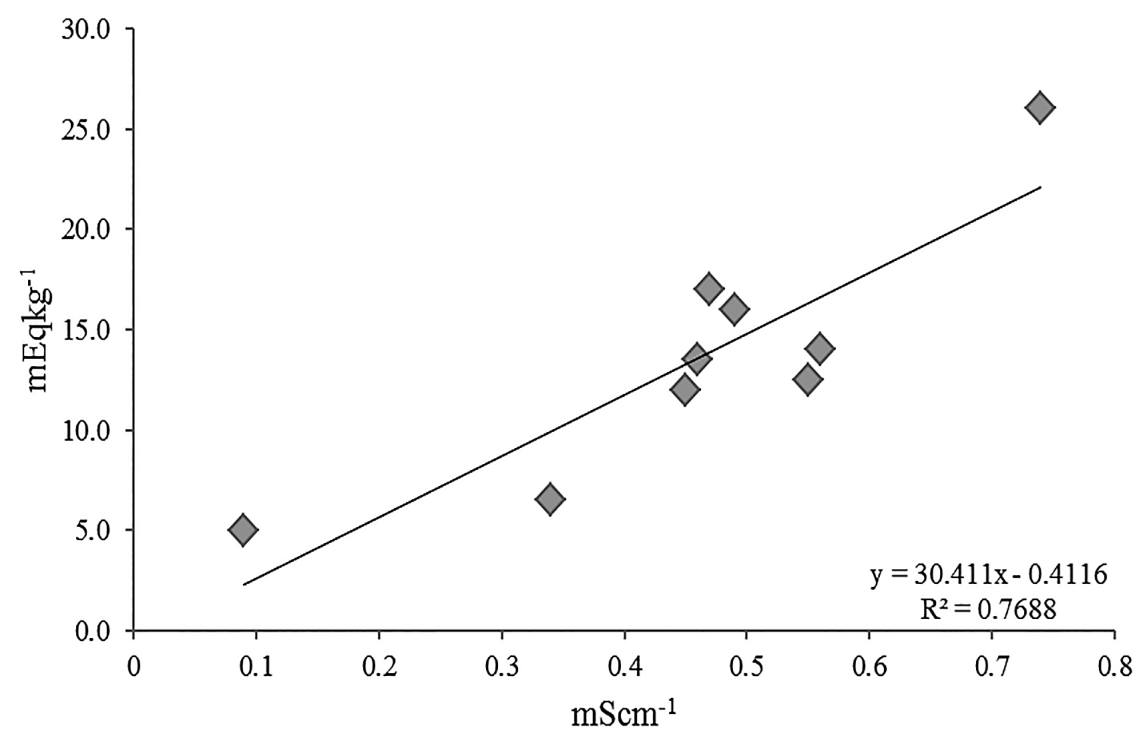

Figure 4. Correlation between acidity and electrical conductivity calculated for polyfloral honey samples. 


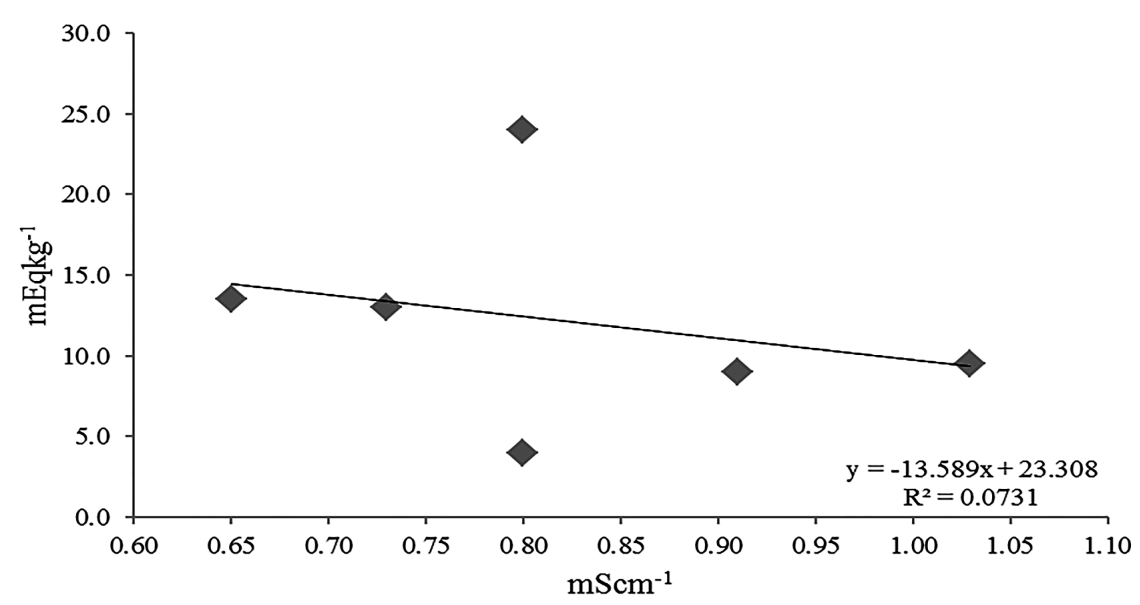

Figure 5. Correlation between acidity and electrical conductivity calculated for forest honey samples.

High correlation was established between free acidity and electrical conductivity only for meadow and polyfloral honey samples $\left(\mathrm{R}^{2}=0.8210\right.$ and $\mathrm{R}^{2}$ $=0.7688$ ).

Acquarone et al. (2007) analyzed honeys of different floral and geographical origin from Argentina. They studied the pattern of electrical conductivity and $\mathrm{pH}$ upon honey dilution by increasing honey concentration. The $\mathrm{pH}$ values decreased exponentially. Such behaviour could be attributed to the fact that, with increasing honey concentration the hydration of fructose and glucose increases and free water decreases. Therefore, the effective concentration of other ions in the solution increased. The authors also reported significant linear correlation between total acidity and free acidity. Finally, they concluded that for a given geographical region, acidity values were useful for discriminating honeys of different floral origins, but that the most adequate parameters for discriminating honeys of different geographical origin were those which described the patterns of $\mathrm{pH}$ and electrical conductivity with changes of honey concentration.

\section{CONCLUSIONS}

The electric conductivity and free acidity of honey collected in an official monitoring in the Republic of Serbia was determined. Free acidity in all tested samples was below $50 \mathrm{meq} / \mathrm{kg}$ indicating the absence of undesirable fermenta- 
tion. Our results demonstrated low acidity of acacia honey and high acidity of forest honey, as compared with other examined honey types. The values of electrical conductivity in the investigated honey samples were between 0.08 and 1.99 $\mathrm{ms} / \mathrm{cm}$. The data indicated the lowest conductivity in acacia honey samples, while the highest conductivity was found in samples of forest and linden honey. Our hypothesis that there is a correlation between the tested parameters is only confirmed for meadow and polyfloral honey samples. In our study, the data on the geographical origin of honey were not available; therefore no other conclusions were made.

The variations in the properties of honey samples illustrated the differences in the botanical origin where honeybees feed. Accordingly, further research on physicochemical properties of honey from Serbia is highly recommended and important in order to set up certification marks and improve criteria for assessing the quality of Serbian honey.

\section{AKNOWLEDGMETS}

The presented work is part of the research done in the project TR31071 granted by the Serbian Ministry of Education, Science and Technological Development.

\section{REFERENCES}

1. Accorti M., Piazza M.G., Oddo L.P.: Electric conductivity and ashes content of honey. Apiacta, 1, 1987.

2. Acquarone C., Buera P., Elizalde B: Pattern of $\mathrm{pH}$ and electric conductivity upon honey dilution as a complementry tool for discriminating geographical origin of honeys. Food chemistry, 101, 695-703, 2007.

3. Boussaid A., Chouaibi M., Rezig L., Hellal R., Donsi F., Ferrari G., Hamdi S.: Physicochemical and bioactive properties of six honey samples from various floral origins from Tunisia. Arabian Journal of Chemistry, 11, 265274, 2018.

4. Chakir A., Romane A., Marcazzan G.L., Ferrazzi P: Physicochemical properties of some honeys produced from different plants in Moroco, Arabian Journal of Chemistry, 9, 946-954, 2016.

5. Codex Alimentarius Commission (2001). Revised Codex Standard for Honey, Codex STAN 12-1981, Rev.1 (1987), Rev.2 (2001).

6. Escuredo O., Dobre I., Fernández-González M., Seijo M.C.: Contribution of botanical origin and sugar composition of honeys on the crystallization 
phenomenon. Food Chemistry, 149, 84-90, 2014.

7. International Honey Commission Methods: Harmonised methods of the International Honey Commission Methods, Swiss Bee Research Centre, FAM, Liebefeld, Switzeland, 2009.

8. Karabagias I.K., Badeka A.V., Kontakos S., Karabournioti S., Kontominas M.G.: Botanical discrimination of Greek unifloral honeys with physicoand chemometric analyses. Food Chemistry, 165, 181-190, 2014.

9. Kirs E., Pall R., Martverk K., Laos K: Physicochemical and melissopalynological characterization of Estonian summer honeys. Procedia Food Science $1,11^{\text {th }}$ International Congress on Engineering and Food (ICEF11), 2011, 616-624.

10. Kropf U., Jamnik M., Bertoncelj J., Golob T.: Linear regression model of the ash mass fraction and electrical conductivity for Slovenian honey. Food Technology and Biotechnology, 46, 3, 335-340, 2008.

11. Official Gazette RS: Rulebook on quality of honey and other bee products, No. 101, 2015.

12. Prica N., Živkov-Baloš M., Jakšić S., Mihaljev Ž., Kartalović B., Babić J., Savić S.: Moisture and acidity as indicators of the quality of honey originating from Vojvodina region. Archives of veterinary medicine, 7, 2, 99-109, 2014.

13. Přidal A., Vorlová L.: Honey and its physical parameters. Czech Journal of Animal Science, 47, 10, 439-444, 2002.

14. Sousa J.M.B., Soza L.E., Marques G., Benassi M.T., Gullon B., Pintado M.M.: Sugar profile, physicochemical and sensory aspects of monofloral honeys produced by different stingless bee species in Brazilian semi-arid region. Food Science and Technology, 65, 645-651, 2016.

15. Yadata D.: Detection of the electrical conductivity and acidity of honey from different areas of Tepi. Food Science and Technology, 2, 5, 59-63, 2014.

16. Vidaković S., Babić J., Knežević S., Pelić M., Jakšić S., Kartalović B., Živkov Baloš M.: Label analysis of Serbian honey: what does (not) the label tell us? Archives of veterinary medicine, 10, 2, 53-62, 2017.

17. Vranić D., Petronijević R., Đinović Stojanović J., Korićanac V., Babić Milijašević J., Milijašević M: Physicochemical properties of honey from Serbia in the period 2014-2016. IOP Conference Series: Earth and Environmental Science. IOP Publishing, 2017, p. 012058, 85.

Primljeno: 13.06.2018.

Odobreno: 01.07.2018. 